\title{
When the Greedy Giant Tumbling Down: Analyzing Nickelodeon's Spatialization Practice in Indonesia
}

\author{
Rizqi Ganis Ashari * \\ Communication Science Program at Universitas Diponegoro Jl.Prof.H.Soedarto, S.H.Tembalang, \\ Tembalang, Kota Semarang, Jawa Tengah 50275
}

\begin{abstract}
The developments of technology and globalization have made the emergence of various changes in media industry. In the entertainment sector various children programs can be broadcasted easily in Indonesia through the cable television industry. Unfortunately, the market share of cable industry is currently experiencing sluggishness. It encourages Nickelodeon to apply certain ways to keep its products dominance in Indonesia. Using spatialization approach in the study of the political economy media, this article aims to describe how Nickelodeon, maintains its product dominance to face that condition. From descriptive qualitative analysis conducted on the news in the mass media and the national company website, found the tendency of localizing strategic alliance both with national companies in the media and non-media industries. Cooperation built between Nickelodeon and the media industry (MNC Group) creates Indonesian-language cartoons and special shows for Indonesian children. Meanwhile, cooperation with non-media companies (Telkomsel and Campina) creates a corporate community base that supports the marketing of Nickelodeon products. The implications of Nickelodeon's collaboration with Telkomsel in the creation of mobile applications are discussed in this article as the social impact of spatialization practices resulting in imbalance of accessing information.
\end{abstract}

Keywords: Nickelodeon; Spatialization; Transnational Media; Indonesia.

\section{Introduction}

The developments of technology and globalization have changed the various aspects of the media industry. In the entertainment sector, technological developments bring changes in the entertainment services for children through the existence of transnational media. One of the giant transnational media which broadcast entertainment programs for children in Indonesian is Nickelodeon. Nickelodeon which owned by the Viacom media group consistently broadcast special programs for children and adolescents in 161 countries, based on its philosophy: "becoming an international children's lifestyle brand, serving as a conduit for connecting kids around the world and acting as a global kid advocate"[1].

Furthermore, the common strategy for transnational media operating in some countries is using cable television. By using this strategy, foreign media can easily map to whom, in what languages, genres, and

\footnotetext{
Corresponding author: ganisashari13@gmail.com
}

content objectives are its programs broadcasted in the targeted countries[2]. Besides, the finance of transnational media company and its operating system will be more efficient by using this strategy[3]. Nickelodeon did the same. In Indonesia, its program can be accessed through television subscription such as BIG TV, Bizznet Home, Indovision, and TransVision.

Unfortunately, based on analysis from Selular.id[4], since 2015 the trend of using cable television in Indonesia tends to decrease[4]. As a result, some cable television providers suffered losses. This condition then leads the transnational media to change the strategy in order to keep its products dominating in Indonesia. Hence, this article aims to describe the way Nickelodeon practiced the concept of spatialization in Indonesia when the cable television industry is currently experiencing sluggishness.

Spatialization is one of the entry points in the study of political economy of communication, which 
want to see the communications industry's attempts to enlarge its institutional strength that manifests in the media, profits, assets, workers, and international markets[3]. One of the major studies in spatialization is research on corporate centralization, the way that companies do to strengthen their dominance in the market by having businesses in production, distribution and communication exchanges, and then lead to minimalize the competition in the media industry which tends to limit the diversity of information to the public[3]. Corporate centralization can be done in several ways; one of them is corporate alliance. The corporate alliance strategy is ranging from product placement in the media, merchandizing deals (allows the third-party to use their product and reproduce it), and contract agreement (intercompany cooperation without any kind of partly or fully ownership)[3]. By using this strategy it is possible that transnational media products spread worldwide through cooperation with local companies in the targeted-country.

This situation led to the concept of localization of media product emerged. Localization is an important strategy for media companies to attract audience by limiting the negative perception as the effect of western culture, but still providing locality for a region[2]. This strategy can appear in several ways: typescript and local language subtitling, hiring local host and production team, build website with local domain, sponsoring local and regional activities, as well as creating a communitybased local company that support transnational media. Localization with the highest degree is the establishment of foreign television to fulfill the needs of regional information[2]. From previous explanation, it is argued that Nickelodeon will cooperate with a localizationbased corporation as its strategy to maintain its dominance in Indonesia. Next part will explain how Nickelodeon collaborates with Indonesian companies as an implementation of spatialization.

\section{Methodology}

The method used in this article is qualitative descriptive. Data collection was conducted during April to June 2017. Data were obtained from two areas: news sites that released news about Nickelodeon cooperation with Indonesian companies and the sites of national companies which establishing alliance with Nickelodeon. In addition, the data will focus on strategies which still continuing in 2016 and will be implemented in 2017.

\section{Discussion}

Cooperation in merchandizing deals was conducted between Nickelodeon and Indonesian ice cream company, Campina. Thus, Campina is allowed to produce ice cream and its packaging in the form of Nickelodeon cartoon's character such as SpongeBob, Teenage Mutant Ninja Turtles, and Avatar. Through this partnership, Campina became the only ice cream in Southeast Asia which has a license from Nickelodeon. Their partnership has been agreed since 2014 and still ongoing today due to the same commitment to produce product that close to children's character[5].

Localization is implemented in the form of creating a local enterprise community base to support the Nickelodeon business. Merchandizing deal becomes prominent because of the concept of connectivity in it. Connectivity may explain that merchandise product never stands alone as a physical product[6]. When someone consumes a merchandise product, he or she will be reminded of a cartoon on television. In the contrary, when watching television, they will remember the merchandise product. In other words, the programs of Nickelodeon act as advertisements to promote their own merchandise products.

Other kinds of strategic alliances built by Nickelodeon are cooperation in the form of contractual agreements between Nickelodeon and two Indonesian companies, MNC Group and Telkomsel. The cooperation between Nickelodeon and MNC Group resulted in a deal of Nickelodeon's cartoons broadcasts on Global TV (such as Rabbids Invasion, SpongeBob SquarePants, Paw Patrols and Blaze and The Monster Machines)[7]. Localization appears when those programs were broadcasted in Indonesian language. Nickelodeon also produces special program for Indonesian children named as Nickelodeon Indonesia Kids Choice Awards, broadcasted on Global TV. Despite just spin off from its international edition, the program is one of localization strategy by taking tremendous effort to involve local celebrity as presenter, artist, and creative team. Beside that, Nickelodeon's annual "Get Dirty!" Earth Day initiative is a call-toaction that supports kids and their projects to help protect the planet. "Get Dirty!" provides kids and their families with information on top-of-mind issues, offers fun ways they can improve the environment and connects them to green activities. Meanwhile, cooperation between Nickelodeon and Telkomsel is the latest cooperation that wants to develop market share in the over-the-top service industry (OTT)[8]. This cooperation allows Telkomsel users to access entertainment contents (game, animated video and live action) in the two applications (Nickelodeon and Nick Jr. Play) through a special data package on their smartphone.

The most important thing we need to underline is the cooperation between Nickelodeon and Telkomsel. This collaboration potentially raises the social impact of spatialization in the form of imbalance information access. To understand that, we must look the concept of cultural imperialism, a concept that describes cultures in developed countries become very dominant in developing countries as a reflection of the economicpolitical dependence of developing countries on developed countries[9]. This critical concept predicts, the end of globalization is the homogenization of values and lifestyles from western societies, because of the pivotal role of transnational media in shaping culture in the developing countries[10][11].

Cultural imperialism in Indonesia is entered through a form of cooperation that is emerged between 
Telkomsel and foreign OTT companies. Before the cooperation discourse with Nickelodeon emerged, as the largest telecommunication service provider in Indonesia, Telkomsel also opened cooperation with other foreign OTTs, such as HOOQ and VIU[12]. Similar to Nickelodeon, the cooperation between HOOQ and VIU creates a policy of internet data packet formation on each of them. From the data package offered, the two OTTs are getting more quota than internet access in general. For example, by purchasing a GIGAMAXBASIC data package for Rp. 49,000 people can only use the data to access internet in general as much as $100 \mathrm{Mb}$. This amount is smaller than quota on Telkomsel's OTT partner which reaches $1 \mathrm{~Gb}[13]$. Besides expensive, it also makes Telkomsel users forced to buy products that they don't really need. This condition depicts the position of people in developing countries that always depend on the dominance of the political economy of developed countries. In short, Indonesian people become consumers whose rights, to use the internet, governed by cooperation between Telkomsel and foreign OTT companies.

This situation is called by Golding \& Murdock (1992:28)[14] as a material barrier on consumers to access the media that actually can be used for the welfare of the wider community. These barriers are related to prices that tend to be expensive so that can't be reached by the whole society and ultimately limit the freedom of the community to access the information they need. Justification on this subject would require more in-depth analysis and study. Further research needs to focus on this aspect, so that empirically it can be known how much information constraints as a social impact of spatialization arises because of the cooperation between the transnational media and telecommunication service providers in Indonesia.

Last but not least, the involvement of Nickelodeon into the Indonesian OTT industry depicts the new form of organizational structure, which combines power to manage resources and flexibility when responding to changes in market share (Mosco, 2009: 169)[3]. This confirms the greed of transnational media giants to remain dominant in a country that is no longer done by conglomeration strategy. Transnational media creates flexible cooperation with national companies, to make new forms of dominance adjusting economic conditions, rules, and technology development that emerges in developing country.

\section{Conclusion}

This paper provides an explanation on how the practice of spatialization by Nickelodeon is done when the growth of cable television industry in Indonesia began to weaken. Based on the analysis conducted, it can be concluded, localization-based strategic alliance is done by Nickelodeon to maintain its dominance. The cooperation in the form of merchandizing deals is done with Campina Ice Cream Company, while the cooperation in the form of contractual agreements is done by cooperating with MNC Group and Telkomsel.
Cooperation built between Nickelodeon and the media industry (MNC Group) creates Indonesian-language cartoons and special shows for Indonesian children. Meanwhile, cooperation with non-media companies (Telkomsel and Campina) creates a corporate community base that supports the marketing of Nickelodeon products.

Further research on the impact of widespread cooperation between other OTTs in general and Nickelodeon in particular, with communication service providers in Indonesia needs special attention. The results of the research can be used to scrutinize the patterns of spatialization in the advanced capitalist era that tend to flexibly adapt technological developments and economic condition. In the end, the findings of the researches can also be used to encourage the creation of affordable internet business so that it can be oriented to the welfare of the community to use the internet without any specific limitations.

\section{References and Notes}

1. R. Denison, Book Review: Sarah Banet-Weiser, Kids Rule! Nickelodeon and Consumer Citizenship, Durham, NC and London: Duke University Press, 2007, Media, Culture \& Society, 31(1) (2009):167-8 (2009).

2. K. Lustyik, Transnational Children's Television: The Case of Nickelodeon in the South Pacific, International Communication Gazette, 72(2) (2010): 171-90 (2010).

3. V. Mosco, The Political Economy of Communication (2nd ed.), California: SAGE Publications (2009).

4. R. Uday, Ditinggal Ribuan Pelanggan, Bisnis TV Berbayar Terancam Buyar, Selular, Retrieved from http://selular.id on April 28, 2017 (2015).

5. D. Baskoro, Campina Gandeng Nickelodeon Rebut Hati Anak-Anak, Retrieved from www.okezone.com on May 1, 2017 (2014).

6. M. Steinberg, A Vinyl Platform for Dissent: Designer Toys and Character Merchandizing, J. Vis. Cul, 9 (2), (2010): 209-28 (2010).

7. Globaltv, Indonesia Kids Choice Awards, Retrieved from www.globatv.co.id on May 2, 2017 (2017).

8. A. A. S. Kusniarti, Telkomsel Perkenalkan Nickelodeon Play dan Nick Jr. Play di Indonesia, Retrieved from www.tribunnews.com on April 28, 2017 (2017)

9. A. O. Thomas, Transnational Media and Contoured Markets (1st ed.), New Delhi, SAGE Publications (2006).

10. Armando, Televisi Indonesia di Bawah Kapitalisme Global (1st ed.), Jakarta, Penerbit Buku Kompas (2016).

11. I. Banerjee, The Locals Strike Back? Media Globalization and Localization in the New Asian Television Landscape, International Communication Gazette, 64(6) (2002): 517-35 (2002). 
12. B. Agung, Gandeng Hooq dan VIU, Telkomsel Hadirkan Layanan Videomax, Retrieved from www.cnnindonesia.com on June 7, 2017 (2016).

13. Telkomsel, Simpati, Retrieved from http://www.telkomsel.com on June 7, 2017 (2017).

14. P. Golding \& G. Murdock (1992), Culture, Communication and Political Economy, Mass Media and Society, ed. J. Curran \& M. Gurivitch, London, Edward Arnold (1992).
15. E. M. Rahayu, Rahasia 42 Tahun Campina Melelehkan Kebekuan Pasar Es Krim, Retrieved from www.swa.co.id on May 1, 2017 (2017). 